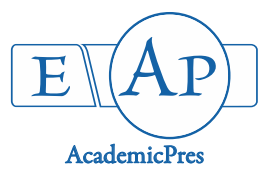

\title{
Anatomy and Micromorphology of Inula belenium subsp. orgyalis and I. ensifolia (Asteraceae) from Turkey
}

\author{
Tulay AYTAS AKCIN ${ }^{1 *}$, Adnan AKCIN ${ }^{2}$ \\ ${ }^{1}$ Ondokuz Mayıs University, Faculty of Science and Arts, Department of Biology, 55139 Samsun, \\ Turkey; aytasakcin@hotmail.com (*correspondingauthor) \\ ${ }^{2}$ Amasya University, Suluova Vocational School, Department of Crop and Animal Production, Programme of Seeding, 05500 Suluova, Amasya, \\ Turkey;adnanakcin@hotmail.com
}

\begin{abstract}
Inula helenium L. subsp. orgyalis (Boiss.) Grierson and Inula ensifolia L. were investigated anatomically and micromorphologically. The secretory cavities in the leaves and stem of both investigated taxa were located in the neighbourhood of the vascular bundles and in the rhizomes in the secondary cortex. The leaf mesophylls of investigated Inula taxa were homogeneous. Stomata were anomocytic in two species. The distribution and density of the eglandular and glandular trichomes provide information of taxonomical significance. Moreover, the cypselas of I. helenium L. subsp. orgyalis were homomorphic, whereas in I. ensifolia cypselas were heteromorphic. Additionally, the number of ribs, the shape of carpopodium and stylopodium were diagnostic taxonomic characters between the two taxa.
\end{abstract}

Keywords: anatomy, Asteraceae, Inula, micromorphology, SEM

\section{Introduction}

The genus Inula L. belongs to the family Asteraceae and comprises about 120 species, distributed mainly in Europe, Africa and Asia (Lack, 2007). In Turkey, there are about 28 species, 33 subspecies and varieties respectively of Inula and 8 of them are endemic. The rate of endemism of Inula species is $28.5 \%$ in Turkey (Güner et al., 2012). I. helenium subsp. orgyalis is an endemic taxon to Turkey (Ekim et al., 2000).

Many of Inula species are antibacterial, antiseptic, antiinflammatory, antiulcerogenic, antipyretic, diuretic, antidiabetic, antirheumatic, antispasmodic, antihaemorrhoidal or anthelmintic (Nickavar and Mojab, 2003). Elecampane (Inula helenium L.) is considered a medicinal herb (Barnes et al., 2007). It is related to the presence of biologically active compounds, such as eudesmanolides, germacronolides, triterpenes, sterols and inulin, in different parts of plants (Sulborska, 2007). Perrot and Paris (1971) reported that I. helenium contains helenin in root. For these reasons, the species is of major interest for many pharmaceutical industries (Nikolakaki and Christodoulakis, 2004).

The use of anatomical and micromorphological characters has also played an important role in the systematic of this genus (Abid and Qaiser, 2004). Deryng (1961) was reported that secretory cavities were found in rays, xylem and phloem of the underground organs of this genus (Bukowiecki and Furmanowa, 1972). However, the information about anatomy of vegetative organs of Inula species is very scarce.

The micromorphological characters such as orientation, shape, size, colour of cypselas and nature of pappus bristles are very important in the seperation of Inula taxa (Jana and Mukherjee, 2012; Jana et al., 2013). Abid and Qaiser (2002) investigated cypsela morphology of Dittrichia, Dubaldea, Inula, Iphiona and Pentanema species from Pakistan and Kashmir and concluded that the morphology and anatomy of cypsela can be useful in identification of distinct taxa.

According to the available literature data, there are no detailed reports on the anatomy and micromorphological characters of Turkish Inula taxa. In this work, it was investigated the anatomy of the rhizome, stem and leaves and micromorphology and distribution of the trichomes on the stem, leaf and cypsela of I. helenium subsp. orgyalis which is an endemic taxon to Turkey and I. ensifflia, by using a light microscope (LM) and scanning electron microscope (SEM).

\section{Materials and Methods}

The plant specimens were collected at the flowering stage from the natural populations of North Anatolia, Turkey. Voucher specimens were deposited in the Herbarium of the Department of Botany, University of Ondokuz Mayıs, Faculty 
of Art and Sciences, Samsun, Turkey (OMUB). Detailed localities of the collected specimens are given in Table 1.

Samples for anatomical studies were fixed in $70 \%$ alcohol. Cross-sections of rhizome, stem and leaves and surface sections of leaves were made by hand. For each structure, at least 30 preparations were observed and their photographs were taken with an Nikon-Coolpix P5100 digital camera. For scanning electron microscopic observations, dried stem, leaves and cypsela samples were mounted on stubs using double-sided adhesive tape and coated with 12.5-15.0 nm of gold. Coated samples were examined and photographed with JEOLNeoscope JCM-5000 Scanning Electron Microscope (SEM).

The following formula was used to calculate the stomatal index (Meidner and Mansfield, 1968):

$\mathrm{SI}=\mathrm{S} / \mathrm{E}+\mathrm{S}$

where SI: Stomatal index; S: guard cells; E: epidermal cells.

The trichome terminology follows Metcalfe and Chalk (1950), Abid and Qaiser (2004) and Jana and Mukherjee (2013).

All anatomical measurements were made using a Image J program on the figures. A total of 19 characters were measured. These characters are given in Table 2. A student's t-test was used to analyse anatomical data and a p-value less than 0.05 was considered as statistically significant.

\section{Results and Discussion}

\section{Anatomical characters}

Comparative anatomical characters of rhizome, stem and leaf of Inula species are presented in Table 2.

\section{Rhizome anatomy}

In transverse section, the outer surface of the rhizome was covered by 4-6 layered periderm of which cells were dark coloured and squashed. In the external layer of cortex, secretory canals were present (Fig. 1). However, the secretory cavities were seen deeper in the cortex of Inula ensifolia L. (Fig. 1). Their shapes were close to rounded or oval. Outside of the phloem ring were located many sclerenchymatic elements. Sclerenchymatic cells were located on the cortical parenchyma. In I. helenium subsp. orgyalis, the pith was occupied with completely metaxylem elements, whereas in I. ensifolia it was parenchymatic (Fig. 1).

\section{Stem anatomy}

Epidermis was consisted of oval or rectangular cells with thick cuticle. The surface was covered with long one or multicellular protective hairs and glandular hairs. Several layers of cortex parenchyma and collenchyma were located beneath the epidermis (Fig. 2). The sclerenchyma fibres covered collateral bundles. The secretory cavities were located in the region of the phloem and xylem bundles (Fig. 2). The pith was formed by the parenchymatic cells that were thin-walled (Fig. 2).

\section{Leaf anatomy}

There was a thin cuticle on the upper and lower epidermis (Fig. 3). Surface of both epidermis was covered with long, multicellular eglandular and numerous glandular hairs. These trichomes were especially located at the lower epidermis. The

Table 1. Detailed localities of the collected Inula L. specimens

\begin{tabular}{cc}
\hline Taxa & Locality \\
\hline Inula helenium L. subsp. & A5 Amasya, Güllüce village, $1,260 \mathrm{~m}$, \\
orgyalis (Boiss.) Grierson & 28.07 .2010$, A. Akcin, OMUB 1552. \\
& A5 Amasya: Ovabaşı village, $1,100 \mathrm{~m}$, \\
Inula ensifolia L. & 25.07 .2010$, A. Akcin, OMUB 1558. \\
\hline
\end{tabular}

Table 2. Anatomical measurements of examined Inula L. taxa. (data are given as mean $\pm \mathrm{sd}, \mathrm{P}<0.05$ denote a statistically difference between two species)

\begin{tabular}{|c|c|c|c|c|c|c|}
\hline \multirow[b]{2}{*}{ Anatomical characters } & \multicolumn{2}{|c|}{ Width $(\mu \mathrm{m})$} & \multicolumn{4}{|c|}{ Length $(\mu \mathrm{m})$} \\
\hline & $\begin{array}{c}\text { I. helenium } \\
\text { subsp. orgyalis }\end{array}$ & I. ensifolia & p-value & $\begin{array}{c}\text { I. helenium } \\
\text { subsp. orgyalis }\end{array}$ & I. ensifolia & p-value \\
\hline \multicolumn{7}{|l|}{ Root } \\
\hline Thickness of periderm & $66.63 \pm 18.667$ & $111.65 \pm 35.466$ & 0.000 & - & - & - \\
\hline Secretory canals in cortex & $135.40 \pm 48.985$ & $24.53 \pm 12.331$ & 0.001 & $181.53 \pm 55.721$ & $137.13 \pm 59.316$ & 0.000 \\
\hline Diameter of trachea & $38.68 \pm 7.952$ & $21.03 \pm 6.073$ & 0.000 & - & - & - \\
\hline \multicolumn{7}{|l|}{ Stem } \\
\hline Epidermis cells & $22.08 \pm 4.317$ & $15.16 \pm 1.808$ & 0.000 & $22.21 \pm 4.517$ & $14.63 \pm 3.257$ & 0.000 \\
\hline Collenchyma cells & $65.82 \pm 19.031$ & $82.04 \pm 6.831$ & 0.001 & - & - & - \\
\hline Parenchyma cells & $311.41 \pm 57.394$ & $34.40 \pm 12.971$ & 0.000 & - & - & - \\
\hline Sclerenchyma cells & $197.82 \pm 55.414$ & $63.55 \pm 17.309$ & 0.000 & - & - & - \\
\hline Secretory canals & $46.09 \pm 13.505$ & $32.56 \pm 11.628$ & 0.000 & $105.43 \pm 21.723$ & $64.94 \pm 10.724$ & 0.000 \\
\hline Thickness of xylem & $180.14 \pm 41.436$ & $218.85 \pm 37.557$ & 0.000 & - & - & - \\
\hline Thickness of phloem & $97.90 \pm 16.107$ & $60.92 \pm 11.295$ & 0.000 & - & - & - \\
\hline Diameter of trachea & $21.79 \pm 4.786$ & $30.17 \pm 11.254$ & 0.000 & - & - & - \\
\hline Diameter of pith cells & $56.36 \pm 15.904$ & $136.51 \pm 54.555$ & 0.000 & - & - & - \\
\hline \multicolumn{7}{|l|}{ Leaf } \\
\hline Epidermis cells & $25.51 \pm 4.780$ & $11.65 \pm 1.478$ & 0.000 & $31.55 \pm 6.391$ & $15.84 \pm 2.761$ & 0.000 \\
\hline Thickness of mesophyll & $74.14 \pm 19.141$ & $203.14 \pm 18.147$ & 0.000 & - & - & - \\
\hline Diameter of trachea & $33.16 \pm 11.253$ & $7.99 \pm 1.855$ & 0.000 & - & - & - \\
\hline Thickness of sclerenchymatous sheath & $121.34 \pm 32.350$ & $59.38 \pm 16.349$ & 0.000 & - & - & - \\
\hline Thickness of xylem & $212.77 \pm 30.418$ & $26.55 \pm 4.663$ & 0.000 & - & - & - \\
\hline Thickness of phloem & $80.18 \pm 8.726$ & $26.55 \pm 4.663$ & 0.000 & - & - & - \\
\hline Stomata & $22.20 \pm 2.410$ & $20.82 \pm 2.281$ & 0.067 & $32.23 \pm 2.720$ & $31.61 \pm 4.099$ & 0.492 \\
\hline
\end{tabular}


106
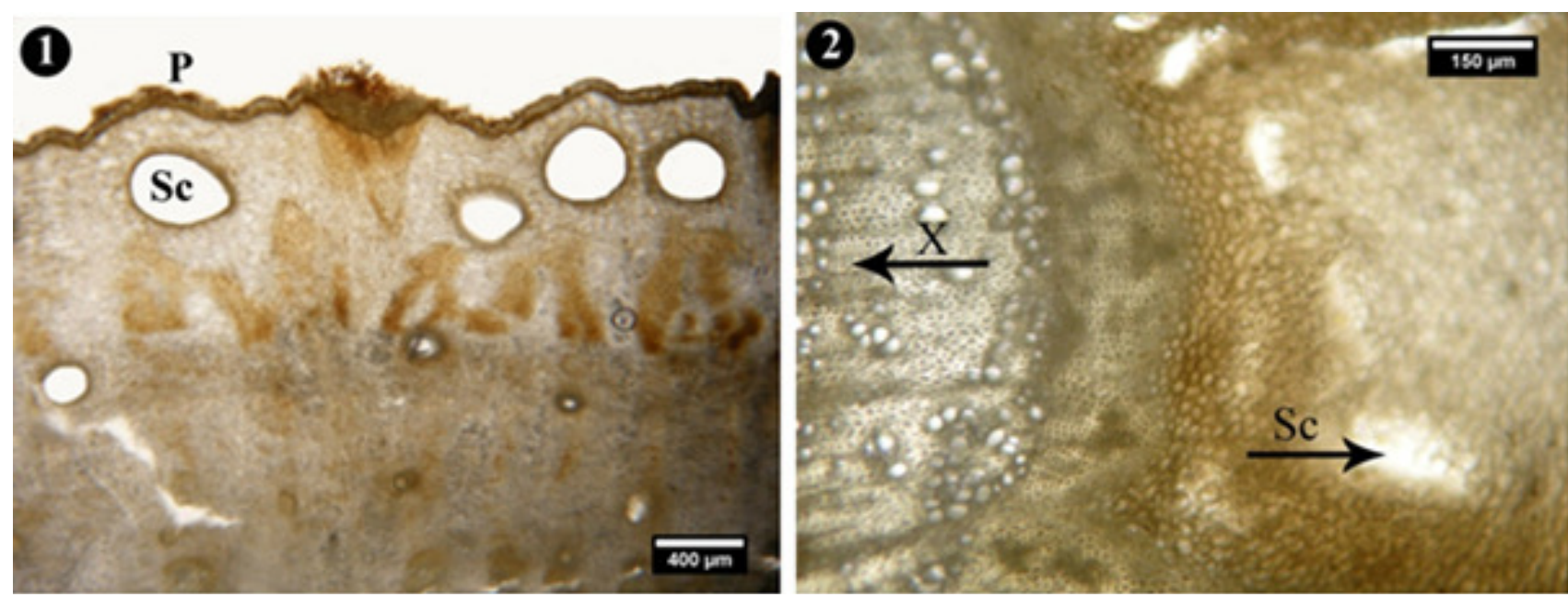

Fig.1.Cross-section of rhizome of Inula species. 1. I. helenium subsp. orgyalis, 2. I. ensifolia. P: periderm, Sc: secretory canals, X:

xylem
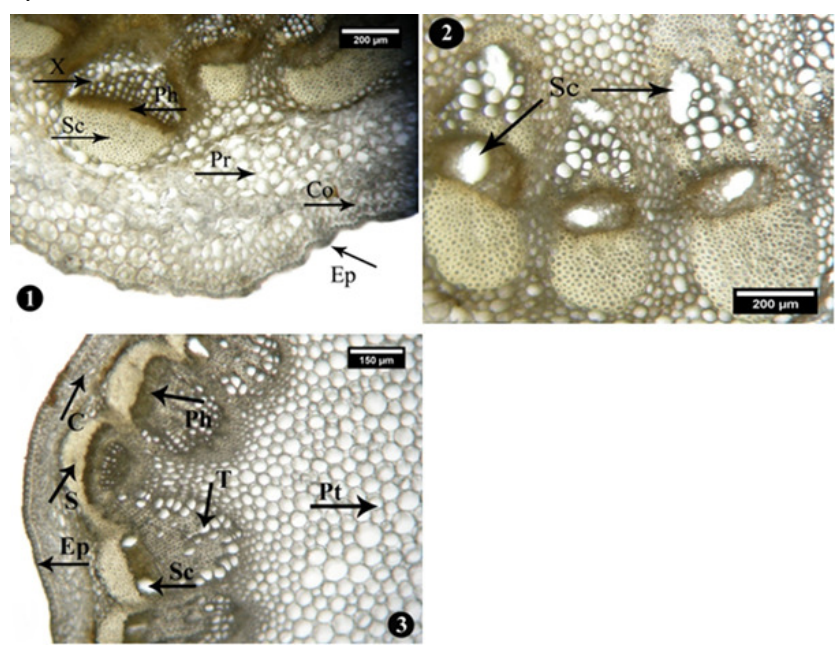

Fig. 2. Cross-section of stem of Inula species. 1-2. I. helenium subsp. orgyalis, 3. I. ensifolia. C: cortex, Ep: epidermis, $\mathrm{Ph}$ : phloem, Pt: pith, S: sclerenchyma, Sc: secretory canals, T:trachea, X: xylem

mesophyll was homogeneous. The anomocytic stomata were located at both epidermis (Fig. 3). However, stomata were especially abundant in the lower epidermis in both taxa. Stomatal index for abaxial epidermis is $20.46 \pm 4.369$ in $I$. belenium subsp. orgyalis and $19.91 \pm 3.212$ in I. ensifolia. Vascular bundles were surrounded by a sheath of sclerenchyma cells (Fig. 3). The secretory cavities were located by the side of the vascular bundles (Fig. 3).

\section{Micromorphological characters \\ Trichome micromorphology}

Two different trichome types on the stem and leaves of the investigated taxa were observed: glandular and nonglandular trichomes. Nonglandular trichomes were acicular or curved and made up from one or more cells (Fig. 4). Glandular trichomes were capitate or peltate with a very short stalk (Fig. 4). Subsessile or sessile glandular trichomes were mostly observed in I. ensifolia. They were common on the abaxial than the adaxial surface of leaves (Fig. 4).

\section{Cypsela micromorphology}

Cypselas were homomorphic in I. helenium subsp. orgyalis, whereas cypselas were heteromorphic in I. ensifolia. In I. ensifolia, disc cypsela was $8.03 \pm 0.14 \times 2.0 \pm 0.21 \mathrm{~mm}$ including pappus, obovate in shape and black. Ray cypsela was $7.04 \pm 0.12 \times 1.0 \pm 0.18 \mathrm{~mm}$ including pappus and black (Table 3). The surface of both cypsela was glabrous (Fig. 5). The number of ribs on cypsela varied: 14 in I. helenium subsp. orgyalis, 11 in I. ensifolia (Table 3). These ribs were present alternating with furrow in both taxa (Fig. 5). The carpopodium was irregular ring like in I. belenium subsp. orgyalis, whereas it was a complete ring-like in I. ensifolia. The stylopodium was inconspicous in I. helenium subsp. orgyalis, but the other taxa was enlarged. In the both cypsela, pappus

Table 3. Cypsela characters of investigated Inula L. taxa

\begin{tabular}{ccc}
\hline Characters & I. helenium subsp. orgyalis & I. ensifolia \\
\hline Type & Homomorphic & Heteromorphic \\
Shape & Oblong-oblongoid & Obovate in disc cypsela \\
& Oblanceolate in ray cypsela & $8.03 \pm 0.14 \times 2.0 \pm 0.21$ in disc cypsela \\
Size $(\mathrm{mm})$ & $7.56 \pm 0.11 \times 1.50 \pm 0.18$ & $7.04 \pm 0.12 \times 1.0 \pm 0.18$ in ray cypsela \\
Colour & Yellow-brown & Black \\
Surface & Rough and glabrous & Glabrous \\
No of ribs & 14 & Complete ring like \\
Carpopodium & Irregular ring like & Enlarged \\
Stylopodium & Inconspicuous & White in disc cypsela \\
Colour of pappus & White-yellow & Yellowish in ray cypsela
\end{tabular}




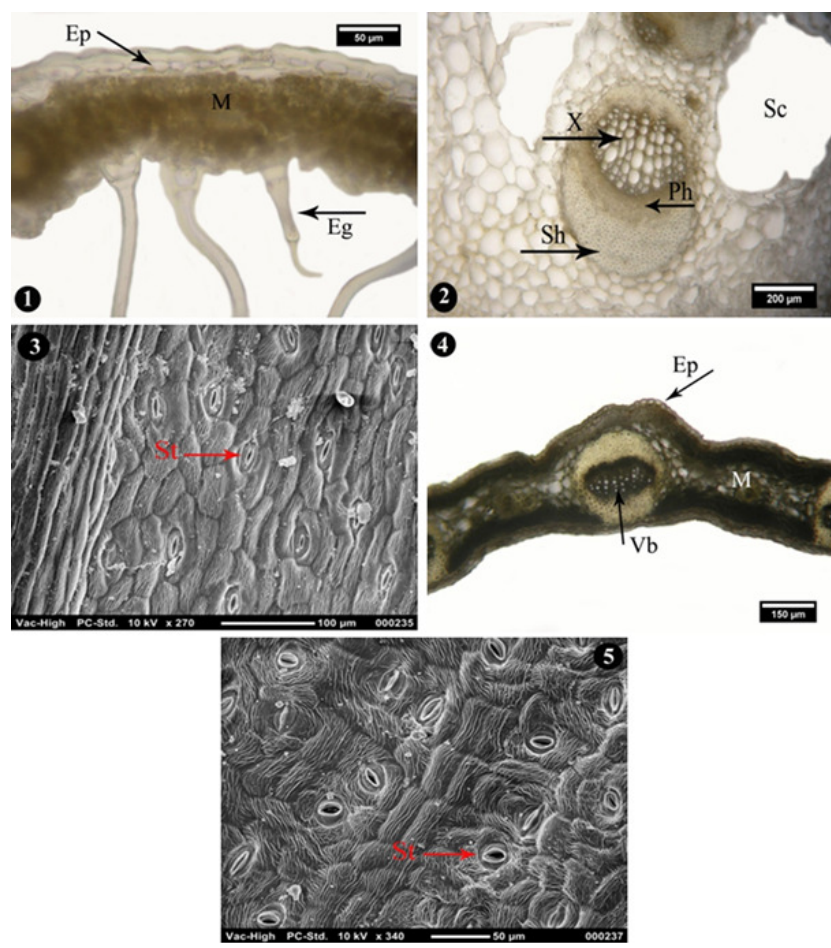

Fig. 3. Leaf anatomical structures of Inula species. 1-2. Crosssection of leaf of $I$. belenium subsp. orgyalis, 3. The lower surface of leaf of $I$. helenium subsp. orgyalis in SEM, 4. Crosssection of leaf of $I$. ensifolia, 5. The lower surface of leaf of $I$. ensifolia in SEM. Ep: epidermis, Eg: eglandular trichome, M: mesophyll, Ph: phloem, Sc: secretory canals, Sh: sclerenchymatous sheath, St: stomata, Vb: vascular bundle

were consisted of serrulate-setose type of pappus bristles. The colour of pappus varied from yellowish to white (Table 3 ).

In the current study, the anatomical and micromorphological characters of I. helenium subsp. orgyalis and I. ensifolia were examined. It has reported that secretory structures and cavities are spread out in the Asteraceae family (Metcalfe and Chalk, 1950; Lersten and Curtis, 1988). As a result of the hereby study, one can conclude that the secretory cavities in the stems and leaves of both taxa were located in the neighbourhood of the vascular bundles and in the rhizomes in the secondary cortex. It was reported that stem and leaf secretory cavities were often located in the vicinity of phloem. This location may be used as an effective protection against phloem-feeding herbivores (Sulborska, 2007). Furthermore, it was shown that the secretory cavities may also contain substances toxic to some herbivores and insects (Maksymowych and Ledbetter, 1987).

On both the analysed species, the rhizome, stem and leaf anatomical structures were similar. However, statistically significant differences were found in mean of the measured all anatomical characters except for stomata length and width (Table 2, P < 0.05). In I. ensifolia, the secretory cavities in the rhizome were smaller and located deeper in the cortex compared to the other species (Table 2). A remarkable difference between taxa in rhizome anatomical structure was seen in pith region. In I. helenium subsp. orgyalis, the pith was occupied with completely metaxylem elements, whereas in $I$. ensifolia it was parenchymatic (Fig. 1).

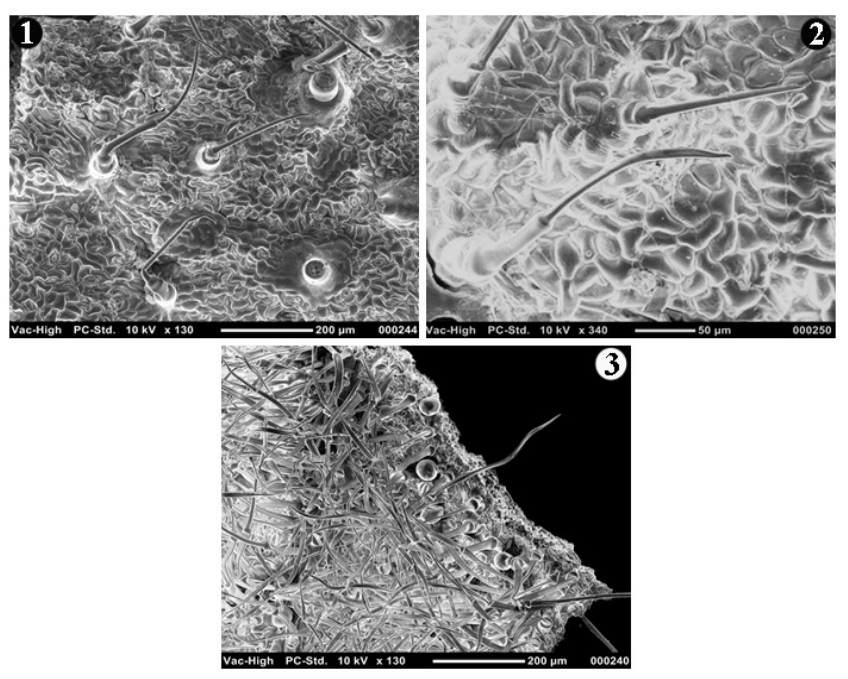

Fig. 4. Scanning electron micrographs (SEM) of trichomes of Inula species. 1. Non-glandular trichomes on stem of $I$. helenium subsp. orgyalis, 2. Eglandular trichomes on stem of $I$. ensifolia, 3. Glandular and eglandular trichomes on leaf of $I$. ensifolia

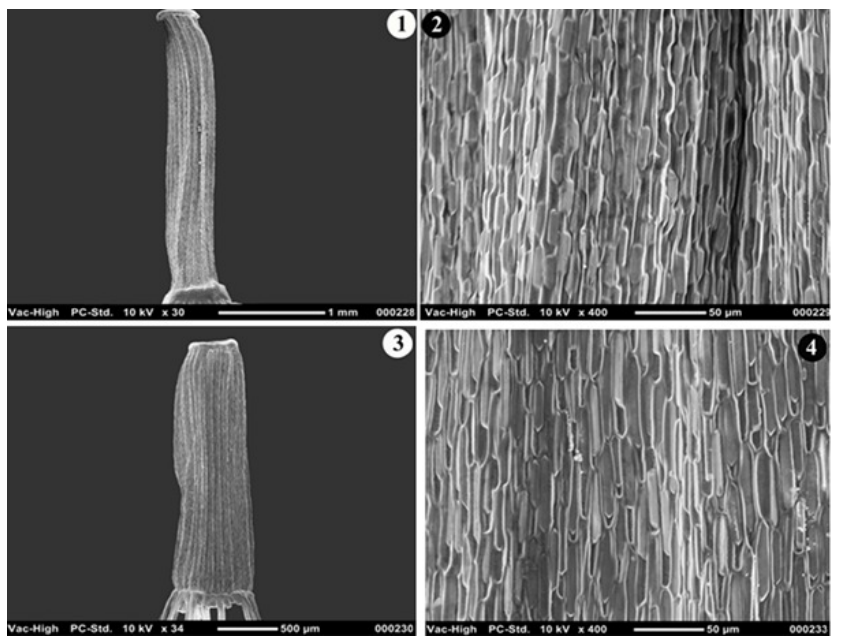

Fig. 5. Scanning electron micrographs (SEM) of cypsela of Inula species.1. General view of cypsela of I. helenium subsp. orgyalis, 2. Surface of cypsela of I. helenium subsp. orgyalis, 3 . General view of cypsela of I. ensifolia, 4. Surface of cypsela of $I$. ensifolia

The stem cortexes were more or less collenchymatized in the both investigated taxa. Some studies on Inula species such as I. britannica and I. germanica reported the existence of an collenchymatic layer in the stem (Toma et al., 2010; Afemei et al., 2011).

The present data are consistent with the results of Toma et al. (2010) and Afemei et al. (2011). There were significant differences in mean thickness of collenchyma, parenchyma and sclerenchyma layer, as well as in the lenght and width of secretory cavities in stem (Table $2, \mathrm{P}<0.05$ ). The dimensions of secretory canals in $I$. helenium subsp. orgyalis were larger than the other Inula taxa (Table 2).

Metcalfe and Chalk (1950) reported that there were generally bifasial mesophylls in the family Asteraceae. In this study, it was seen that mesophyll was homogeneous in 
108

investigated both Inula taxa (Fig. 3). Toma et al. (2010) observed that some Inula species such as I. oculus-christi, had homogeneous mesophyll, whereas I. germanica had dorsiventral mesophyll. The current results basically agree with the findings of Metcalfe and Chalk (1950). However, from Table 2, it is evident that the mesophyll in the leaf was thicker in I. ensifolia.

Furthermore, in I. ensifolia the sclerenchymatous sheat around the phloem was significantly wider (thicker) compared to that in midribs of $I$. helenium subsp. orgyalis leaves (Table 2). Diameter of vascular bundles in I. helenium subsp. orgyalis was much wider than that of those found in $I$. ensifolia (Table 2, $\mathrm{p}<0.05$ ). This difference in thickness of sclerenchymatous sheath may be probably correlated with protection of the vascular bundles.

According to the results from the present study, the investigated two taxa have anomocytic stomata on both leaf surface (Fig. 3). It was reported that there were both anomocytic and anisocytic stomata in the family Asteraceae (Metcalfe and Chalke, 1950). Toma et al. (2010) determined that some Romanian Inula species have anomocytic stomata. The present findings are consistent with the results of Toma et al. (2010).

Studies of trichomes in Asteraceae have been found to be diagnostic by many researchers (Adedeji, 2004; Adedeji et al., 2007). In the present study, it was found that stem and leaf epidermis of both taxa have eglandular and glandular hairs (Fig. 4). Similar types of trichomes were observed in most of Inula species (Adedeji, 2004; Adedeji et al., 2007). However, distribution and density of the eglandular and glandular trichomes of I. helenium subsp. orgyalis were more abundant than I. ensifolia. Similarly, eglandular trichomes were shorter in I. ensifolia than the other investigated taxa. Also, glandular trichomes in I. ensifolia were sessile or subsessile, while in I. helenium subsp. orgyalis were mostly capitate or peltate (Fig. 4). The distribution of these trichomes may provide additional evidence to delimination of Inula species.

Investigated Inula species were distinguishable on the basis of cypsela micromorphology. Cypselas were homomorphic in I. helenium subsp. orgyalis, whereas in $I$. ensifolia, cypselas were heteromorphic (Fig. 5). In addition, the number of ribs, the shape of carpopodium and stylopodium were diagnostic taxonomic characters between studied Inula taxa. In I. ensifolia, stylpodium was enlarged, while in other studied species it was inconspicuous. In the present study, it was determined that carpopodium is an important taxonomical character. In I. helenium subsp. orgyalis, carpopodium was irregular ring-like. However, symmetric carpopodium observed in I. ensifolia. Jana et al. (2013) and Shekhar et al. (2011) reported that the characters of carpopodium and stylopodium of cypselas of the tribe Inuleae have taxonomic significance. The current results confirmed the existent data from the literature.

Finally, based on the results of the present study, it may be concluded that some of the micromorphological and anatomical characters are useful to distinguish within the species of the genus Inula. Further researchs on anatomical and micromorphological structure of the other Inula species could also provide insight into classification of Inula taxa.

\section{Conclusions}

The present paper demonstrated significant anatomical and micromorphological differences among two Inula L. taxa from Turkey. In I. ensifolia, the secretory cavities in the cortex were smaller and deeper in the rhizome. In addition, in $I$. belenium subsp. orgyalis, the pith was occuped with metaxylem elements, whereas in I. ensifolia it was parenchymatic. There were significant diffrences in mean thickness of collenchyma, parenchyma, sclerenchyma layer, the length and width of secretory cavities in stem. The leaf mesophyll of I. ensifolia was thicker than the other species. Furthermore, in I. ensifolia the sclerenchymatous sheath was significantly thicker compared to I. helenium subsp. orgyalis leaves. From all the studied micromorphological characters, the distribution and density of the eglandular and glandular trichomes was found to be most useful to deliminate the species.

\section{References}

Abid RD, Qaiser M (2002). Cypsela morphology of Inula L. (s.str.) and its allied genera (Inuleae-Compositae) from Pakistan and Kashmir. Pakistan Journal of Botany 34(3):207-223.

Abid RD, Qaiser M (2004). A micromorphological study for the generic delimitation of Inula L. (s. str) and its allied genera (InuleaeCompositae) from Pakistan and Kashmir. Pakistan Journal of Botany 36(4):719-724.

Adedeji O (2004). Leaf epidermal studies of the species of Emilia Cass. (Senecioneae, Asteraceae) in Nigeria. Botanica Lithuanica 10(2):121-133.

Adedeji O, Ajuwon OY, Babawale OO (2007). Foliar epidermal studies, organographic distribution and taxonomic importance of trichomes in the family Solanaceae. International Journal of Botany 3(3):276-282.

Afemei M, Boz I, Toma C (2011). Histo-anatomical aspects refering to the vegetative organs of two species of Inula $\mathrm{L}$. from Romanian Flora. Ştiintele Naturii 27(1):23-28.

Barnes J, Anderson LA, Phillipson JD (2007). Herbal medicines (3rd ed), Pharmaceutical Press, London pp 85-101.

Bhar I, Mukherjee SK (2004). Macromorphological and micromorphological study of cypselas in seven species of the tribe Anthemideae (Asteraceae). Journal of Economic and Taxonomic Botany 28(3):788-794.

Bukowiecki H, Furmanowa M (1972). Botanika Farmaceutyczna. PZWL, Warszawa pp 443-450.

Deryng J (1961). Atlas sproszkowanych roślinnych surowców leczniczych. PZWL, Warszawa.

Ekim T, Koyuncu M, Vural M, Duman H, Aytaç Z, Adıg̈zel N (2000). Türkiye Bitkileri Kırmızı Kitap [Red Data Book of Turkish Plants], Ankara: Turkish Association for the Conservation of Nature, No 18 pp 245.

Güner A, Aslan S, Ekim T, Vural M, Babaç MT (2012). Türkiye Bitkileri Listesi (Damarlı Bitkiler), [A Checklist of the Flora of Turkey, Vascular Plants]. İstanbul: Flora Araştırmaları Derneği ve Nezahat Gökyiğit Botanik Bahçesi Yayını. 
Jana BK, Mukherjee SK (2012). Cypselar morphology of some species of the family Compositae and their taxonomic significance. International Journal of Pharma Sciences and Research 1(5):463484.

Jana KR, Bar R, Mukherjee SK (2013). Cypselar morphology and anatomy of five species of the tribe Inulea-Asteraceae. International Journal of Pharma Sciences and Research 4(1):911-919.

Lack HW (2007). Tribe Cichorieae Lam. \& DC. In: Kubitzki K (Ed). The families and genera of vascular plants, Vol 8, Flowering plants: Eudicots, Asterales. Berlin, Springer pp 180-189.

Lersten NR, Curtis JD (1988). Secretory reservoirs (ducts) of two kinds in giant ragweed (Ambrosia trifida; Asteraceae). American Journal ofBotany 75 (9):1313-1323.

Maksymowych R, Ledbetter MC (1987). Fine structure of epithelial canal cells in petioles of Xanthium pensylvanicum. American Journal of Botany 74(1):65-73.

Metcalfe CR, Chalk L (1950). Compositae. In: Anatomy of the dicotyledons. Leaves, stem and wood in relation to taxonomy with notes on economic uses. Clarendon Press, Oxford pp 782-804.
Nickavar B, Mojab F (2003). Antibacterial activity of Pulicaria dysenterica extracts. Fitoterapia 74:390-393.

Nikolakaki A, Christodoulakis S (2004). Leaf structure and cytochemical investigation of secretory tissues in Inula viscosa. Botanical Journal of Linnean Society 144:437-448.

Perrot E, Paris R (1971). Les plantes médicinales (I). Presses Universitaires de France, Paris.

Shekhar S, Pandey AK, Anderberg AA (2011). Cypsela morphology and anatomy in some genera formerly placed in Inula (Asteraceae: Inuleae-Inulinae). Rheeda 21(1):13-22.

Sulborska A (2007). Distribution and structure of internal secretory reservoirs on the vegetative organs of Inula belenium L. (Asteraceae). Acta Agrobotany 60(1):1-12.

Toma C, Grigore MN, Afemei M, Stanescu IE (2010). Histoanatomical considerations on some romanian Inula L. species, with pharmacological action. Analele Ştiințifice ale Universității Al I Cuza, Iaşi, Secțiunea a IIa. Biologie pp 5-13. 